\title{
Safe Spaces for Disruptive Learning in a North-South Research Partnership Context: International Mobility of Doctoral Students
}

\author{
Lilian Julia Trechsel ${ }^{1, *(\mathbb{D})}$, Anne Barbara Zimmermann ${ }^{1}$, Camilla Steinböck ${ }^{1}$, Thomas Breu ${ }^{1}$, Karl Herweg $^{1}$ \\ and Susan Thieme ${ }^{2}(\mathbb{D}$ \\ 1 Centre for Development and Environment (CDE), University of Bern, 3012 Bern, Switzerland; \\ anne.zimmermann@unibe.ch (A.B.Z.); camilla.steinboeck@unibe.ch (C.S.); thomas.breu@unibe.ch (T.B.); \\ karl.herweg@unibe.ch (K.H.) \\ 2 Institute of Geography, University of Bern, 3012 Bern, Switzerland; susan.thieme@giub.unibe.ch \\ * Correspondence: lilian.trechsel@unibe.ch; Tel.: +41-631-52-71
}

check for

updates

Citation: Trechsel, L.J.;

Zimmermann, A.B.; Steinböck, C.;

Breu, T.; Herweg, K.; Thieme, S. Safe

Spaces for Disruptive Learning in a

North-South Research Partnership Context: International Mobility of Doctoral Students. Sustainability 2021,

13, 2413. https://doi.org/10.3390/ su13042413

Academic Editor: Eila Jeronen

Received: 31 December 2020

Accepted: 15 February 2021

Published: 23 February 2021

Publisher's Note: MDPI stays neutral with regard to jurisdictional claims in published maps and institutional affiliations.

Copyright: (c) 2021 by the authors. Licensee MDPI, Basel, Switzerland. This article is an open access article distributed under the terms and conditions of the Creative Commons Attribution (CC BY) license (https:// creativecommons.org/licenses/by/ $4.0 /)$.

\begin{abstract}
This article spans issues of international student mobility, inequalities in higher education, and spaces for transformative learning for sustainable development. We tracked PhD alumni of an international Swiss research program in 2012 and 2017 and found that students from the global South experienced a significant, immediate career boost; most graduates decided to remain in or return to their country of origin after graduation (brain circulation). Career advancement among global North students took longer to develop. In-depth interviews with selected graduates gave students a voice: they felt empowered by networks, new friendships, and working relationships across disciplinary boundaries. The "safe spaces" or "Third Spaces" created in the program-encompassing inter- and transdisciplinary approaches, institutional and cultural diversity, and a real-world focus-were key for transformative learning, supported by an unconventional teaching and research strategy. To support disruptive learning leading to changes in mindsets and to reduce inequality in higher education, Western universities must question their own privileged position.
\end{abstract}

Keywords: education for sustainable development; interdisciplinary approach; international student mobility; alumni; North-South; Third Space

\section{Introduction}

As key sites of learning for students in increasingly mobile education landscapes, universities and similar higher education institutions have a complex role. They are hubs where knowledge is produced, transmitted, and stored according to historically developed, somewhat rigid epistemological and physical structures, corresponding with separate disciplines. However, they must also remain flexible to accommodate evolving fields of inquiry and societal needs [1]. As brick-and-mortar institutions, higher education institutions are still very much place-based, with certain geographic areas developing reputations for "excellence" that are deployed to attract mobile students in line with current "commodified" understandings of higher education.

Educational research, for its part, has gradually moved away from its initial placebased bias-reflected in studies of classrooms or campuses-to embrace wider spatial concepts and issues of mobility, enabling analysis of education and learning according to broader, decentered understandings [2,3]. In this new scholarly debate, authors emphasize the interconnectedness and spatial relations of mobile knowledge. Higher education institutions are seen as interconnected via mobile norms, values, curricula, educational policies, and especially students-evidenced particularly by international students visiting and travelling from one institution to the next [4].

International student mobility (ISM) has increased markedly in recent decades. According to UNESCO, nearly all countries have recorded a rise-some even experiencing a 
doubling or tripling of international students in the last decade [5,6]. Most ISM research fails to give students themselves a voice or an opportunity for self-reflection [7-9], with a few notable exceptions (e.g., see [10-12]). This is a missed opportunity: ISM is worth exploring not only because of its contribution to the reputations of higher education institutions and professional programs, but also because of how it is shaping knowledge systems through the experiences and career decisions of individual students [13].

By listening to the voices of mobile students, the present article addresses this first gap to better understand what PhD graduates' experience of mobility entails beyond career implications and whether they are being sufficiently equipped to respond to changing societal needs locally and globally. For example, how do programs address the urgent, internationally negotiated goals of the 2030 Agenda for Sustainable Development, which require scientists to engage more strongly and assume responsibilities beyond generating data [14]? How do they respond to the call for research that does more than conduct ostensibly "value-free" studies [15]? Such questions are particularly relevant when focusing on doctoral $(\mathrm{PhD})$ degree programs, as students who complete them typically face major decisions about continuing in academia or seeking senior positions elsewhere.

Higher education institutions can no longer afford narrow assumptions about employability or requisite skills. Today's global challenges [16] such as climate change or inequality require long-term, globally oriented programs that train PhD candidates and future leaders to address global challenges with a critical mind. These programs must also help to build evidence-informed consensus and develop solution-oriented approaches, particularly by cooperating closely with stakeholders from outside academia [17-20]. Proponents of education for sustainable development (ESD) increasingly emphasize the need for tertiary education focused on development of specific competences including skills in systems thinking, anticipatory methods, normative issues, strategic approaches, and interpersonally [21] as well as the application of sustainability knowledge in future job settings [22]. Aside from knowledge and competences, ESD also requires helping students develop relevant attitudes [23] and the ability to incorporate values in scholarly work [24]. To develop attitudes and values enabling them to address real-world sustainability issues, students need a "safe space" where they can experience the emotional learning edge that triggers transformative learning moments [25,26] through disruptive learning [27,28].

However, the dominant understandings of science largely remain structured along disciplinary lines, despite increasing numbers of inter- and transdisciplinary research centers. Academic disciplines strive to obtain or defend their own privileged position in the research landscape, often trapping themselves in "silo thinking" [29]. Prevailing teaching formats and curricula largely reproduce this disciplinary approach. In academia, especially at the PhD level or above, disciplinary specialization is emphasized and "outputs" like peer-reviewed articles enable individual scientists to advance their careers, while enabling their "home" institutions to improve their international rankings.

Overall, attitudes of competition (e.g., between researchers, disciplines, and institutions) continue to dominate knowledge-production processes in science. One especially unfortunate consequence of this is the reproduction of global inequalities between countries of the global North and South [30,31]. Historical divides between former colonial powers and occupied countries, for example, now arguably show up as resource divides-not least of all in their scientific capacities. In particular, the distribution of researchers across the world is highly uneven: according to recent figures, low-income countries average only 66 researchers per million inhabitants, 50 times fewer than OECD (Organisation for Economic Co-operation and Development) countries [6]; and all low-income countries combined account for as little as $0.3 \%$ of global research spending [14]. This low researcher density, combined with limited scientific tradition and inadequate access to established research communities and journals, seriously hampers low-income countries in their academic development and continues to drive many talented young students from the global South to study abroad. 
Although Switzerland is a globally connected country in terms of student mobility and higher education, it has only recently become the focus of ISM research [32,33]. Against this background, the present article addresses the second gap of disciplinary thinking and marketized higher education impeding proper sustainability orientation of universities and ISM by examining a unique survey of PhD alumni from around the globe who participated in a 12-year North-South research partnership program funded by Swiss donors, known as the National Centre of Competence in Research (NCCR) North-South. Participants were trained in an intercultural, interdisciplinary setting with a focus on science for sustainable development [34]. The program sought to reduce North-South science inequality while advancing research to tackle societal problems according to a combined disciplinary, interdisciplinary, and transdisciplinary approach. Participants pursued a disciplinary $\mathrm{PhD}$ but also received a supplementary degree in recognition of their research focus on sustainable development. Altogether, $222 \mathrm{PhD}$ candidates from around the world received training through the program, also giving rise to a unique student population sample for this research. Most of the students from the global South and North were officially enrolled at a home-country university, but had the chance to meet and collaborate with fellow $\mathrm{PhD}$ candidates from other countries and disciplines during program fieldwork, training, and conferences. In the present article, we take a particular look at the program's annual "summer school", which enabled PhD students to discuss and interact beyond their disciplinary boundaries in challenging real-world contexts.

This article seeks to analyze how the NCCR North-South program enabled PhD researchers to advance their academic careers and simultaneously afforded them innovative learning opportunities on behalf of sustainable development. It draws on two alumni tracking surveys and follow-up interviews designed to access the students' individual mobility experience, trace their career pathways, and understand how alumni perceived their ability to tackle sustainability issues in their research. We focused on the following two questions:

- How did students perceive the training setting of the program, and did it support them in their desire to address today's global challenges?

- How did the alumni benefit from an inter- and transdisciplinary North-South research network in terms of their career path and future work?

Specifically, the present research examined the career pathways of $78 \mathrm{PhD}$ alumni according to a mixed-methods approach, with a view to determining where these $\mathrm{PhD}$ alumni stood at the time of the survey. The qualitative research portion used semi-structured interviews to give the $\mathrm{PhD}$ alumni a voice; it particularly investigated how students experienced learning spaces designed to disrupt disciplinary expectations during their $\mathrm{PhD}$ training. The literature review that follows in the next section places the present study in a framework combining several spheres of interest: ISM studies, inquiries into education inequalities, studies on the role of science for sustainable development, and reflections on spaces for transformative learning. This review was conducted by the authors individually, in their specific areas of expertise, and results were shared in several writing workshops to consolidate the analytical framework for this paper.

\section{Academic Mobility-Cementing Global Inequalities?}

\subsection{International Students with Transnational Networks}

In 2017, UNESCO counted over 5.3 million international students, that is, students pursuing all or part of their tertiary education in a country other than their home country. Indeed, the number of international students more than doubled in less than two decades, from 2 million in 2000 [35]. Numerically, international student mobility (ISM) is driven mainly by non-Western countries, especially China, India, and South Korea. Students from Africa are less mobile and their enrolment rate in tertiary education is significantly lower. Looking ahead, the role of these countries-especially in Africa-will only grow in prominence, as they will host and send the majority of globally mobile students [30]. 
ISM is more than an exchange of financial and human capital. It opens up broader questions of interactions between the global and the local on highly uneven geopolitical and socio-economic ground. Globally, the relationship between knowledge hubs is being discussed in terms of the "academic West" and the "academic rest" [30]. "Western" degrees, in particular, are associated with many benefits including language and intercultural skills, and a greater degree of self-reliance (e.g., see [36-38]).

As agents of knowledge production, students pass through different education and spatial contexts during their academic careers, often settling only temporarily in higher education institutions. Instead of identifying individual "push" and "pull" factors (e.g., economic) to understand ISM, connectivity can serve as a model to analyze the career pathways of students and dynamics of knowledge formation [4]. According to Baumann, et al. [30], (p. 194), "a university can be a portal acting on its own account, and it can be a portal if the government wants it to be one. In both scenarios, connectivity to the world can be strategically steered [ . . . ] The university has gained significant importance and can be considered empowered under the global condition".

Young people who study abroad are more likely to maintain a transnational lifestyle and transnational networks with multiple ways of identification. Some settle in a foreign country temporarily, others permanently (e.g., see $[9,39])$. Their decision to study abroad can be partly understood based on assumptions about prospective returns on investments in education for individual students, but also for their families and communities as a whole; these calculations are not made in a void, but rather within socially distinct value systems and in relation to various mobility practices. The relevance of social networks in shaping and sustaining migration processes has been intensely debated and acknowledged since the 1970s (e.g., see [13,40-43]). A new focus of ISM research has emerged in the context of the UN's Agenda 2030 [44], addressing the question whether ISM and related alumni associations are contributing to advancing social change in lower and middle-income countries [13]. While social networks are based on personal relationships [13], they are also strongly shaped by power relations and should not be discussed without considering such relationality $[9,45,46]$, which is also key in the context of transformative learning for sustainable development [47].

\subsection{Power Asymmetries in Higher Education}

Debates on power and mobility emphasize the difficulty of forging equitable networks and describe the uneven power constellations shaping interactions between spatially dispersed actors and places [48-50] including dominant opportunity-oriented imaginaries of mobility versus the reality of potential disappointments when studying abroad (e.g., see [37]). Besides carrying multiple responsibilities related to their family background and home countries, international students often confront challenges with the requirements of Western academic structures and epistemologies based on the assumed primacy of Western higher education [9]. As sites of education, universities are shaped both by within-country national priorities and by international competition [4]. Both levels inhere within fundamental relations of power. Numerous students and faculty worldwide have criticized the increasing commoditization of universities and called for the protection of fundamental values of free (higher) education [30]. According to Baumann et al. [30], many universities currently struggle to serve different societal needs and work for harmony in the world, while simultaneously adapting themselves to the marketization of knowledge and education. Among other things, this reproduces power asymmetries between the global North and South.

In the context of research for sustainable development, this fundamental contradiction must be addressed. Lange [51] does so by linking postcolonial theory and a critique of transformative learning theory, introducing the concept of relationality and Bhabha's Third Space [52] — a space where cultural meanings are dynamically negotiated, bringing about new hybrid identities in a process of cultural translation and contestation. In postcolonial and transformative learning debates [28,51], facilitation of such a space is seen 
as a way of overcoming the dichotomy of "self" and "other" as well as the postcolonial condition that impedes transformation toward more equitable and sustainable interaction between peoples and institutions. However, such efforts in higher education remain the exception [19].

Depending on the performance of "their" universities in standardized rankings, states increasingly seek to position themselves globally [30]. When examining global university rankings, universities from the global South seem to fall off the map. They largely appear poorly financed, lacking quality, and insufficiently networked with other universities. However, in terms of raw numbers, it quickly becomes clear that Africa, Asia, and Latin America are home to the majority of the world's students and higher education institutions, possessing major promise in terms of human capital [30]. Existing ISM studies, however, focus almost exclusively on major "sending" countries (e.g., China, South Korea, India) and "receiving" countries/continents (e.g., North America, Europe, Australia) in the global knowledge system, thus reproducing rather than questioning the geography of higher education hierarchies.

Discussions of unequal student mobility between the global South and North typically refer to the concepts of "brain drain", "brain gain", and "brain circulation". Brain drain debates go back to 1960s-70s research on student and skilled-labor mobility from the global South to the North; they expressed a concern about the loss of "brain power" in the South due to the attractiveness of living in the North after having benefitted from a Northern scholarship. Brain gain and circulation debates gained momentum in the 1990s, when researchers and policymakers began acknowledging that migrants (for education) did not necessarily sever ties with their home countries, but rather fostered international connections, leading to gains for the global South. Migrant students and laborers sometimes gained knowledge and experience abroad and applied it upon returning home [13,32,53-58]. Several recent studies on post-graduation mobility have shown that many students do not return to their "sending" countries [59-61]. These studies appear to confirm long-running concerns about brain drain, while simultaneously perpetuating a somewhat misleading emphasis on Western countries. As noted by others, "Student mobility is a process largely driven by students from non-Western countries, a fact that is often overlooked by assessing impacts on host institutions or debates about brain drain" [30, p. 197]. However, brain gain and circulation have also been observed in the context of studies with a focus on social engagement and sustainability impact (e.g., see [13]), supporting the idea that motivates programs such as the NCCR North-South or the Ford Foundation International Fellowships Program [11,12].

\subsection{The NCCR North-South: An Inter- and Transdisciplinary Research Network}

The link between knowledge, place, and power is particularly relevant in the context of research for sustainable development [62]. This understanding informed the design and implementation of the NCCR North-South program from 2001 to 2013 [63]. The program's aim was to investigate pathways for sustainable development. It also gave PhD students from the global South a chance to participate in an international research network while simultaneously studying at or through their home university $[64,65]$. Much of the research was conducted by PhD candidates associated with one of the many partner universities. A shared PhD graduate program was created to support students in their efforts to understand and master the tasks of inter- and transdisciplinary research. They participated in an annual two-week summer school in a local setting-often, but not exclusively, in global South countries-including a tailored fieldwork component and interdisciplinary, intercultural activities [66]. Students were selected by the participating institutions in consultation with the candidates and their supervisors. The guiding criteria for selecting students were thematic fit with each summer school's focus and completion of the definition phase of a candidate's PhD project. All students were required to attend one summer school in the course of their PhD. Thus, all students in the program experienced mobility to different countries on different continents, regardless of their university of 
enrolment, yet remained locally rooted to their home university, while closely collaborating with other research institutes and the wider program research group [58]. This often inspired discussions about the many differences between university systems and an acute awareness of the relationality of the academic system. The summer school continues to be carried out in different parts of the world. It was and is an intercultural learning setting — arguably a Third Space, as articulated by Bhabha [52]—in which PhD candidates collaborate in interdisciplinary groups.

Besides training PhD students, the program's two-week summer school is used to train future trainers (i.e., junior and senior lecturers still unfamiliar with the training approach needed for research for sustainable development—an approach quite similar to an education for sustainable development (ESD) approach). Indeed, it has become clear that international students need learning settings that go beyond traditional classroom experiences and enable the development of the skills, methods, and attitude required to address global challenges in an interdisciplinary, team-oriented manner $[5,8,20,67]$ and that these settings are not available at their home institutions.

\section{Sample and Methods}

To identify and understand the pathways of the international program's alumni and their perceptions of their trajectories, we adopted a mixed-methods approach [68]. Our starting point was an alumni tracking survey of graduates from the NCCR North-South program, first conducted in 2012 [58] and repeated five years later. The program brought together $222 \mathrm{PhD}$ students from eight regions, with research occurring in 40 countries and involving 140 organizations in Africa, Asia, Latin America, and Europe [63]. The first alumni tracking survey was designed as part of the program's internal impact monitoring "to find out whether the NCCR North-South's aims were achieved, specifically with regard to capacity development and career building" [58] (p. 7). The second tracking initiative additionally sought to obtain insights into the graduates' career trajectories by means of qualitative interviews. Following the rules of qualitative research, we anonymized the answers of our respondents and provided maximum background information on our research to the interviewees; in addition, the research project received clearance from the program's scientific board.

\subsection{Alumni Tracking Survey 2012 and 2017}

The methods used for the first alumni tracking survey in 2012 are described in detail in Heim et al. [58]. We summarize this description here: the questionnaire was developed based on an intensive review of the program's proposal and ten years of annual reporting, and on an outcome monitoring framework set up for the program by the management center. A focus group discussion of the questionnaire was then organized with the regional coordinators of each partnership region. Finally, the questionnaire was tested with five alumni. The questionnaire (Supplementary A) captured the alumni's self-assessments regarding all program levels including the perspectives of coordinators and participants from the program regions. The second alumni survey in 2017 adopted the same questionnaire, but eliminated a few items (see Supplementary B). The second survey was conducted online via LimeSurvey in January 2017. About two-thirds (111) of the possible respondents (181) were the same as those surveyed in 2012. The others (70) were graduates who completed their degree between 2012 and 2017, in the context of a newly established successor program, the International Graduate School (IGS) North-South. All but two participants had begun and conducted most of their $\mathrm{PhD}$ research within the original NCCR North-South program or a direct follow-up project. In total, 170 former doctoral students were successfully contacted. Of these, 103 responded to the online survey and 78 completed it, resulting in a satisfactory participation rate of 45.9\% [69-71].

The 2017 survey data were analyzed using Microsoft Excel. This provided initial insights into the demographics, career development, and life phases of the $\mathrm{PhD}$ graduates. In sorting the survey data, all participants were grouped according to their geographic 
country of origin; their results were then divided into the categories "global North" and "global South" and analyzed accordingly. This classification-particularly important in the context of the NCCR North-South program-was done according to the official United Nations HDI, or Human Development Index [72]. The cutoff was made at an HDI of 0.8: all countries with a "very high" HDI were classified as "North", and those with a HDI below 0.8 were classified as "South" [72]. Tables 1 and 2 show that the demographic breakdown and the socio-economic background of survey participants in 2017 were very similar to that of the 2012 survey.

Table 1. Overview survey sample in 2017 and 2012 regarding gender and origin.

\begin{tabular}{ccccc}
\hline & \multicolumn{2}{c}{$\mathbf{2 0 1 2}$} & \multicolumn{2}{c}{$\mathbf{2 0 1 7}^{\mathbf{1}}$} \\
\hline Geographic Origin & Male & Female & Male & Female \\
\hline North & $18(22 \%)$ & $21(25 \%)$ & $11(14 \%)$ & $23(30 \%)$ \\
South & $33(40 \%)$ & $11(13 \%)$ & $35(46 \%)$ & $8(10 \%)$ \\
\hline Total & $51(62 \%)$ & $32(38 \%)$ & $46(60 \%)$ & $31(40 \%)$ \\
\hline
\end{tabular}

Data sources: NCCR North-South alumni tracking surveys, conducted in 2012 and 2017. The largest group consisted of male alumni from the global South $(2017,46 \% ; 2012,40 \%)$ and the smallest group consisted of female alumni from the global South $(2017,10 \% ; 2012,13 \%)$. A survey of scientists in African countries and UNESCO data confirm this picture of over-represented male researchers [73]. ${ }^{1}$ In the 2017 sample, one participant failed to indicate their country of origin.

Table 2. Breakdown of survey sample in 2017 and 2012 regarding socio-economic background (self-assessed class, parents' education level).

\begin{tabular}{|c|c|c|c|c|}
\hline \multirow[t]{2}{*}{$\begin{array}{l}\text { Geographic } \\
\text { Origin }\end{array}$} & \multicolumn{2}{|c|}{$\begin{array}{c}2012 \\
\text { Socio-Economic Background }\end{array}$} & \multicolumn{2}{|c|}{$\begin{array}{c}2017^{1} \\
\text { Socio-Economic Background }\end{array}$} \\
\hline & $\begin{array}{c}\text { Lower Class or } \\
\text { Lower-middle Class }\end{array}$ & $\begin{array}{l}\text { Upper-middle Class } \\
\text { or Upper Class }\end{array}$ & $\begin{array}{c}\text { Lower Class or } \\
\text { Lower-middle Class }\end{array}$ & $\begin{array}{l}\text { Upper-middle Class } \\
\text { or Upper Class }\end{array}$ \\
\hline North & $13(34 \%)$ & $26(66 \%)$ & $15(44 \%)$ & $19(56 \%)$ \\
\hline \multirow[t]{3}{*}{ South } & $29(65 \%)$ & $15(35 \%)$ & $29(67 \%)$ & $14(33 \%)$ \\
\hline & \multicolumn{2}{|c|}{ Both Parents' Highest Academic Degrees } & \multicolumn{2}{|c|}{ Both Parents' Highest Academic Degrees } \\
\hline & $\begin{array}{l}\text { Attended no formal school } \\
\text { or reached primary or } \\
\text { secondary school }\end{array}$ & $\begin{array}{c}\text { Achieved a } \\
\text { post-secondary degree }\end{array}$ & $\begin{array}{l}\text { Attended no formal school } \\
\text { or reached primary or } \\
\text { secondary school }\end{array}$ & $\begin{array}{c}\text { Achieved a } \\
\text { post-secondary degree }\end{array}$ \\
\hline North & $4(10 \%)$ & $35(90 \%)$ & $4(12 \%)$ & $30(88 \%)$ \\
\hline South & $23(52 \%)$ & $21(48 \%)$ & $20(47 \%)$ & $23(53 \%)$ \\
\hline
\end{tabular}

Data sources: Responses from the global South alumni concerning their socio-economic background were very similar between 2017 and 2012. In 2017, 67\% of the Southern participants indicated having a lower class or lower-middle class background-versus $65 \%$ in 2012. In contrast, while $66 \%$ of global North graduates classified themselves as having an upper-middle class or upper class background in 2012, only $56 \%$ did so in 2017. To find out more about the socio-economic background of the $\mathrm{PhD}$ graduates, the alumni survey inquired about both parents' highest academic degree. The 2012 and 2017 results were comparable, revealing a striking difference between the South and North: In 2017, 88\% of Northern students' parents had achieved a post-secondary degree (vs. 90\% in 2012); whereas 47\% of Southern students' parents had no formal schooling or only reached primary or secondary school (52\% in 2012). ${ }^{1}$ In the 2017 sample, one participant failed to indicate their country of origin.

\subsection{Semi-Structured Interviews}

Qualitative data collection took place in April and May 2017 using semi-structured interviews designed to deepen insights from the quantitative survey data and bring the graduates' own perspectives on their experience to light. After a first analysis of the interview data and coding results, we also tried to elucidate whether alumni had any "transformative" learning experiences while in the sustainable-development research program, and whether the program enabled a Third Space [52] or "safe space" for learning (see [25]) where disruptive moments $[27,28]$ were possible, leading to epistemological insights and changes of mindsets in the context of a multidisciplinary, multicultural, and multi-institutional reality. 
Interviewees were selected based on Flick [74] using criteria chosen for their adequateness to explore our research questions: gender balance; representation of the NCCR North-South program's focus regions (West Africa, East Africa, Horn of Africa, Central Asia, South Asia, Southeast Asia, Central America, South America, Swiss Alps); doctoral thesis defended during different phases of the 12-year program; and balance between submission of thesis in country of origin versus submission in a foreign country. This resulted in a selection of eight respondents, of whom only seven agreed to an interview. One of the remaining interviews was excluded from the dataset because it was marred by technical difficulties during the Skype session. Thus, six interviews were analyzed. The interviewees were from Colombia (female, 49 years, PhD in 2008), Kyrgyzstan (female, 41 years, PhD in 2014), Nepal (male, 51 years, PhD in 2006), Kenya (female, 39 years, PhD in 2013), and Switzerland (female, 32 years, PhD in 2014; and male, 30 years, PhD in 2016).

The semi-structured interviews were structured to enable open and flexible handling of the sessions [74]. Interviewees were informed in advance about the purpose and focus of the interviews, providing them with some orientation and the freedom to speak openly about their personal experiences during the program. The interview guide consisted of four main questions with sub-questions. One question aimed at finding out about their social networks. A second question asked about the career pathway of the alumni including information about geographic movement, job positions, and job opportunities. A third question aimed to find out whether they thought their work in the academic context had an impact on today's global challenges. The fourth question was specifically about the support $\mathrm{PhD}$ candidates had experienced through the program; this question was supplemented by the quantitative survey questions (see Supplementary A, questions 48-53 and Supplementary B, questions 34-37). To limit the length and scope of interviews, no question focused on social distinctions. After obtaining the respondents' informed consent, the interviews were recorded and then transcribed verbatim. The questionnaire contained four main themes: social networks, description of career pathways, experiences within academia, and graduate school support.

The interviews were analyzed using the program MaxQDA, based on Döring and Bortz [75]. First, a within-case analysis was done by working through each interview transcript to gain an overview of the content. Next, the data were coded, with codes generated deductively based on the research questions as well as inductively based on insights gained from the interviews. This led to two main codes: Knowledge and Collaboration. In a follow-up stage, cross-case analysis was carried out to apply the generated codes to all interviews. The categories were further developed and compared with each other, requiring additional revision of the codebook to adapt to all cases. As a result, the two main categories Knowledge and Collaboration were then subdivided into subcategories, namely: (i) under Knowledge: diploma, meaning of $\mathrm{PhD}$, program aspects, North-South differences, summer school, skills, and push/pull elements; and (ii) under Collaboration: intercultural aspects, research/education collaboration and networks. The theme of "safe space" emerged after analyzing the results of the second coding round as a result of the high rate of mentions of the effect of the summer school on the PhD candidates' learning experience. This iterative thematic analysis was done by authors LT and CS, leading to identification of the most-relevant topics across all cases in the context of the research questions. The analysis also shaped a subsequent literature review. In a final step, the codes were grouped into seven thematic areas: networks, career pathways, career boost, submission, work in academia, motivation for $\mathrm{PhD}$, and summer school. Several questions emerged from this inductive procedure: What forms of interaction and transformative spaces did the alumni experience? What in the program setting did the students consider enabling of career advancement? What forms of liminality did students experience, if any? What were the related limitations of the program? 


\section{Results and Discussion}

\subsection{Brain Circulation and Alternative Pathways to Reduce Inequality}

The study results captured the spatial mobility of alumni in terms of their place of origin and their place of residence at the time of the second survey in 2017. At this time of data collection, most of the alumni (73\%) resided in their home country and held a working position there. Table 3 provides an overview of the PhD graduates' North-South mobility after completing their degree. Altogether, only $14 \%$ of the program alumni from the global South moved to a country in the global North after completing their degree, in stark contrast to dominant "brain drain" findings by others. These quantitative results confirm the picture obtained in the original NCCR North-South alumni survey in 2012, which also showed that most students from Southern countries stayed in their place of origin or returned to it [58].

Table 3. Geographic movement after completing their PhD.

\begin{tabular}{cc}
\hline Geographic Movement & Number and Percent of Students ${ }^{1}$ \\
\hline Student Category North & \\
\hline North to North & $9(26 \%)$ \\
North to South & $2(6 \%)$ \\
No movement & $23(68 \%)$ \\
\hline Student Category South & \\
\hline South to South & $3(7 \%)$ \\
South to North & $6(14 \%)$ \\
No movement & $34(79 \%)$ \\
\hline
\end{tabular}

${ }^{1}$ One survey participant did not indicate their country of origin or country of current residence.

Furthermore, the survey findings suggest that the NCCR North-South program addressed education inequality within the scope of its network, evidenced by two-thirds of its alumni from the global South classifying their family background as lower class or lower-middle class in both the 2017 and 2012 surveys. Moreover, the program noticeably provided a career boost to smart young people from low-income and low-educated family backgrounds. This advancement is evidenced by comparison of the work positions held by students before and after graduation, at the time of the second survey (2017). Table 4 shows that in the global South, most alumni $(81 \%)$ held a position as an employee, intern/trainee, or in middle management before starting their $\mathrm{PhD}$. A minority of students (12\%) already had a leading position prior to joining the program. After finishing their $\mathrm{PhD}$, the number of global South alumni who held a leading position increased to $49 \%$. In the global North, most alumni (56\%) indicated having an employee position prior to starting their $\mathrm{PhD}$; this share remained about the same (50\%) after earning their $\mathrm{PhD}$ degree. At the same time, the percentage of leading positions held by global North students increased after graduation from $3 \%$ pre- $\mathrm{PhD}$ to $20 \%$ post- $\mathrm{PhD}$ - a significant improvement, though less than that experienced by Southern students. Only one participant was still in a lower-level intern/trainee position after completing their $\mathrm{PhD}$ (an alumna from the South)—all others advanced. Taken together, the results of the second survey (2017) confirmed the original survey (2012) results showing a significant and immediate career impact of PhD completion for students, especially in the global South. Furthermore, the latest survey results also confirmed the trend suggested by Eva Heim et al. [58] that PhD graduates in the global North required longer to obtain a leading position than those in the South. Finally, the 2017 survey echoed the 2012 results showing that most alumni worked in academia after graduation. 
Table 4. Professional positions of alumni before their PhD and position in 2017.

\begin{tabular}{ccccc}
\hline Professional Position & \multicolumn{2}{c}{ North } & \multicolumn{2}{c}{ South } \\
& Position Before PhD ${ }^{\mathbf{1}}$ & Current Position ${ }^{2}$ & Position Before PhD & Current Position ${ }^{2}$ \\
\hline Leading position & $1(3 \%)$ & $7(20 \%)$ & $5(12 \%)$ & $21(49 \%)$ \\
Middle management & $5(16 \%)$ & $6(18 \%)$ & $13(30 \%)$ & $10(23 \%)$ \\
Employee & $18(56 \%)$ & $17(50 \%)$ & $15(35 \%)$ & $7(16 \%)$ \\
Intern, trainee & $7(22 \%)$ & $0(0 \%)$ & $7(16 \%)$ & $1(2 \%)$ \\
Independent & $1(3 \%)$ & $4(12 \%)$ & $3(7 \%)$ & $4(10 \%)$ \\
\hline
\end{tabular}

${ }^{1}$ In the sample in category North, two participants failed to indicate their position before their PhD. ${ }^{2}$ "Current position" is the position in 2017 at the time of the survey.

The location where PhD students submitted their thesis was always the place of the university where they were enrolled. The data showed that the alumni from the global South obtained leading positions irrespective of whether they submitted their PhD thesis at a Northern or Southern university. Half (50\%) of Southern graduates whose PhD title was awarded by a Northern university held a leading position at the time of the second survey, and almost half $(47 \%)$ of those who submitted their thesis at a Southern university also held leading positions. This confirms the findings of a survey of African universities, showing the great need for academic staff with $\mathrm{PhD}$ degrees throughout the continent [76]; to our knowledge, this need is also strong in other countries of the global South, though with regional differences.

In total, 53 alumni submitted their thesis at a Northern (European, American, or Chilean) university, most (46) in Switzerland. Another 24 alumni submitted at a Southern university. Notably, not one Northern PhD candidate submitted his or her thesis at a Southern university. However, virtually all fieldwork was conducted in the global South (Africa, Asia, Latin American, Caribbean, Central Asia, India, Sri Lanka, and Southeast Asia). Only three surveyed alumni conducted their fieldwork in the global North, specifically in Switzerland, their country of origin. Looking at the relationship between students' place of university enrolment and place of fieldwork, the importance of spatial context emerges clearly. As agents of knowledge, the students pass through various spatial stages according to life-course trajectories [2], settling only temporarily in most cases.

The data depict various alumni pathways, but the overall picture is of high mobility during the fieldwork stage, followed by the resettlement of most study participants (two-thirds) to their country of origin after graduation. The majority of fieldwork was done in countries in Africa, Asia, South and Central America-with the exception of a handful of candidates from the global South who did research in the global North (mainly Switzerland), enabling unique scientific insights into Northern contexts from researchers with different cultural backgrounds [77,78].

Looking closer at Southern alumni, we observe that $79 \%$ of them remained or returned to their country of origin after graduation. This aligns with "brain circulation" theories of academic mobility [53,55], with students gaining knowledge and skills during their $\mathrm{PhD}$, sharing this knowledge with diverse stakeholders in different parts of the world, and fostering connections between countries [79]. It highlights the potential of skilled $\mathrm{PhD}$ graduates from the global South to play key roles in their countries of origin while cultivating and benefitting from a global network. However, the complete absence of Northern alumni submitting their thesis at Southern universities points to the ongoing devaluation of Southern higher-education institutions [30]. Nonetheless, it is exceptional that half $(51 \%)$ of the Southern students were based and enrolled at a university in their country of origin while pursuing a PhD funded by Switzerland. About two-thirds of students were fully or partly funded by the NCCR North-South program, while one-third was associated and funded independently through other projects [63]. 


\subsection{Empowering Space for Transformation}

\subsubsection{What Forms of Interaction and Possibly Transformative Spaces Did} Students Experience?

The results from the in-depth interviews indicate how the students perceived the space in which they conducted their PhD work and what they considered empowering within the NCCR North-South program. According to the survey data, a significant majority of alumni (over $80 \%$ ) stayed in contact with fellow graduates. The main reasons cited for staying in contact were friendship (66\%) and/or general networking (44\%). Another key reason for ongoing contact was continued research on a shared topic or region. Less strong was networking solely for career reasons. As shared by one graduate:

The networks you build also inform you in many other aspects. Apart from just academia, they also give you aspects on social interactions [and] cultural background[s] [ ... ] they spice up your life, and you start to see things in a different way. (Kenyan woman)

Strong connections and ongoing networks between alumni were particularly emphasized by respondents in the in-depth interviews. Alumni described writing proposals together and cultivating bonds in research and professional collaborations. They mentioned the strong support they provided to each other and the importance of social media such as Facebook and LinkedIn. For real-time communication, they often used Skype to exchange and talk, but they also continued to use email. Furthermore, alumni benefitted from extended networks based on shared supervisors and other key academic contacts.

As Baláž et al. [4] highlighted, connectivity and linked spatially diverse knowledge acquisition play a major role in understanding relationships between students. The importance of maintaining academic contacts has also been shown in other studies [13,79]. Collaboration and partnership-based research enabled students in the NCCR North-South program to co-author articles and share the weight of pressure in competitive academic surroundings, as described by the interviewees. Students gradually developed working relationships, especially by designing project proposals together. The networks they created, called "allies" by one interviewee, also gave rise to later job opportunities. Alumni offered support to each other by sharing knowledge and material, and helping to build their respective careers. However, their networks were more than only academic collaborations, they were shaped by the element of friendship. This sense of friendship among members is also highlighted as a key finding in the alumni study by Campbell and Baxter [13].

Friendly connections, mostly kept up via social media platforms and email, were actively cultivated and alumni took advantage of their international contacts when travelling. Student collaboration and networks extended beyond the alumni circle and program graduation, reaching from South to North and vice versa, encompassing academia as well as high-level decision-makers. The networks fostered crucial exchange opportunities including invitations to conferences and keynote speaker requests.

I already had some network. But the PhD has given me another network. [ ... ] So I get connected to lots of PhD researchers, university people, and high-level government decision-makers. (Nepali man)

As noted by Baas [39] and Rizvi [9], transnational networks open up many opportunities for students. One interviewee said that the international setting gave her the opportunity to "sit on two chairs". She was able to maintain her existing job, providing economic security for herself and her family, while simultaneously pursuing a PhD linked to a wide network. She and others also had access to a broader-based supervisory team, comprising experts from the global North and South. Importantly, the project design of the NCCR North-South program enabled flexible institutional arrangements adapted to each local context. During the annual summer school course, participants had the opportunity to play different roles (e.g., student, peer-teacher, and supervisor) and to experience shifting perceptions of the "self" and "other". Moreover, during research, they assumed diverse roles while co-producing knowledge for sustainable development [80]. The "training of 
future trainers" program component was cited by interviewees as highly valuable for affording self-reflective learning within a nascent community of practice.

You need that. And it's not just being trained and that's it. You also need to be trained to train others. (Kenyan woman)

Overall, the program provided transnational and social networking opportunities through which students exchanged knowledge and information. Additionally, the networks and meetings created a space in which students forged new friendships. This important form of in-person meetings is also mentioned in the research by Campbell and Baxter [13]. The annual summer school provided room for testing things out, reflecting on and practicing different roles, and experiencing an empowering "safe space" [25] or Third Space [52] with disruptive moments leading to completely new insights linked with changes of practice (especially scientific practice) and changes of attitude with regard to identities-both ones' own and that of others. These participatory spaces for learning are also highlighted in the work of Sallah [28].

\subsubsection{What Program Elements Supported Career Advancement among Alumni?}

The structure of the NCCR North-South program included a supervisory team comprising different mentors, typically a local partner and another supervisor. This was both challenging and enriching for students and supervisors, as described by one student from Kyrgyzstan:

My research [ ... ] was something new for the local science [and] academia [... ] which made me proud and, also, I think it was good for the country. [ ... ] I had a local supervisor who, you know, through this joint research [ ... ] she got introduced to some new concepts. [ ... ] especially [those of the] older generation in the former Soviet Union [lack] foreign language skills, so they do not always have access to the latest, in terms of publications, in their field. (Kyrgyz woman)

This co-supervisory structure meant that local partner universities also had an important stake in the research projects, based on institutional agreements with the Swiss program. It expanded the horizon of many participating supervisors, enabling them to deepen themselves in a new research approach focused on sustainable development, also echoing the conception of Phelps [8] regarding the valuable role of locally rooted institutions connected to transnational spaces. This advantage of the NCCR North-South program was also explicitly underlined by the eight Regional Coordinators, who provided a number of examples of positive academic, professional, and institutional impacts of supervision arrangements. In addition, the substantial funds available and the sheer size of the network and its sustainability orientation, also led to the initiation of new collaborative projects and mobilization of resources, establishment of new academic programs and curricula, integration of interdisciplinary and transdisciplinary research in existing programs, efficient management of research, internal training, and improved supervision visibility and recognition of organizations [65] (pp. 36-39). Only a few criticisms of how supervision took place were expressed [65] (pp. 58-59).

The survey data showed that many alumni continued working in interdisciplinary $(55 \%)$ and/or transdisciplinary (32\%) teams. During the summer school course, students learned to navigate an intercultural, interdisciplinary, and transdisciplinary setting. Interview respondents repeatedly highlighted the importance and eye-opening nature of this course:

[The summer schools] were all interdisciplinary. Some [participants] were hardcore biologists, hardcore soil scientists, others from the human sciences, so all bringing together, discussing it, so you widen your part and widen your discussions. (Nepali man)

On the one hand, students had to overcome challenges of collaborating with colleagues from different disciplinary backgrounds, a typically disruptive learning moment that was purposefully triggered by one of the group exercises of the summer school [56]. On the 
other, students drew inspiration from the diversity of perspectives and opportunities to receive or provide mentorship. Conducting fieldwork as a group in a transdisciplinary setting including developing a research strategy with local stakeholders demanded and fostered open attitudes, interpersonal responsiveness, understanding, and acceptance of differing worldviews and cultural perspectives [15].

The prevailing spirit of sharing and exchange also included making knowledgeproduction methods and knowledge publication accessible to all. Providing open access to materials was deemed crucial and integrated in the partnership principles [64] and in the program's publication strategy [81]. In the annual summer school, participants experienced innovative teaching-and-learning arrangements that concretized education for sustainable development. Supported by theoretical and methodological sessions, the core of the summer schools was an exploratory case study involving preparation, fieldwork, analysis, and presentations, followed by peer-review processes. This case study-based approach encompassed five to seven days of training, in which students played an increasingly active role and assumed more responsibility for their learning, while the instructors increasingly acted as coaches. The case studies always addressed real-life development issues in the respective local context, allowing both intense interdisciplinary work with other students of different disciplines as well as transdisciplinary encounters with local actor groups. While attending the course-especially the fieldwork component—students gained skills for future work environments requiring collaboration with diverse stakeholders.

Just this whole approach of [learning] how to set up a research project. That you include various points of view and, if possible, also involve [local] stakeholders and then formulate research questions based on their statements. I really benefited from this. (Swiss man)

\subsubsection{What Negative Experiences of Liminality and Mobility Did PhD Students Have?}

A key stumbling block mentioned by interviewees was that of self-perceived rootlessness, presenting challenges to their sense of identity. Some students felt in limbo and not necessarily able to experience the liminal, transnational program space in a fully empowering way.

I don't feel at home. [ . . . I feel comfortable [ ... ] but I don't feel at home. I think there are a lot of things that are not mine [ ... ]. I don't belong to everything, but that became stimulating. (Colombian woman)

Grimshaw and Sears [7] state that young international students are always challenged to negotiate and make sense of their identity. They emphasize the importance of the social environment of international student migrants, also highlighting how lifetime trajectories and language skills strongly influence their actions.

Furthermore, according to the interviewees, it is not always reasonable to educate students at the $\mathrm{PhD}$ level when they come from a completely different context and education standards diverge widely. The interviewees cited becoming aware of knowledge gaps when studying in different countries. National education standards are set in different ways and often not comparable-sometimes causing unwillingness to recognize or value certain foreign degrees and vice versa.

My objective was to come back to Colombia and to have this [Swiss] title. And I think there is a better value, I think. And for [Switzerland] I am sure that if I had a diploma from Colombia it would be not recognized. (Colombian woman)

A major divide between Northern and Southern universities can be observed regarding the perceived substance and quality of these educational institutions. Indeed, the geographic "place" of universities still matters a great deal, with top schools competing to gain the best students and make their institution as attractive as possible. While looking at global rankings, universities in the global North dominate while countries from the global South can scarcely be found [82]. Several African countries are not even included in university rankings. Interviewees pointed to the dominance and prestige of European, North American, and some Asian universities: 
Particularly in political science or international relations, it is seen as better if you go to a university in Canada or the US. These university rankings and the high prestige afforded to European and American universities, in contrast to African universities, I find it problematic. I experienced it myself while doing a simultaneous exchange in America, at Columbia University, and in the Congo at another university. And, well, what I did at the university in the Congo doesn't count for anything in Europe. (Swiss woman)

This highlights complex issues of science inequality in development research. On the one hand, countries in the global South are arguably valued, in particular, as sites for fieldwork. While collecting data during fieldwork in the global South, students obtain "international experience" and burnish their sustainable development credentials. On the other hand, these countries are devalued as places for data analysis and teaching. The "knowledge" obtained in the field is often taken back to the global North, along with the resulting prestige.

Even if people want to, even if people are capable of doing a PhD, not everybody can afford to [ ... I In addition to being a long process, in addition to being a difficult process if you are really working on your research, it's also expensive. [People] like teachers with local salaries, they cannot afford such expenses. (Kyrgyz woman)

Finally, another well-known stumbling block are education costs, which especially hinder talented students from the global South. Baumann [30] confirms that students from African countries are less mobile than other international PhD students, with the rate of tertiary education enrolment lower overall in Africa. This, too, reinforces inequality in education.

\subsection{Third Space and Relationality: Conditions for "Space for Transformation"}

The interview results also provide insights into the students' increasing feeling of agency as researchers, spurred by the unconventional learning space facilitated by the program, and by the multiple opportunities for networking and relating to one another in an "in-between" setting in which the foundations for research for sustainable development were being negotiated [83]. Students appreciated that their task as researchers was not just to produce knowledge, but rather to develop skills for an engaged form of science.

I feel like the PhD showed me how to start something, take responsibility, and keep going and find solutions when things get difficult. [ . . . Besides the theoretical and empirical knowledge you gain during the PhD, these soft skills are really important. (Swiss woman)

In our literature review, we described the necessity of addressing the discourse on inequalities in education and aptitude in science, especially science that aims to support society in the difficult path toward sustainable development. In our view, this can only take place in a "safe space" [25] or a Third Space [51] where hybridity is possible and relationality becomes the driving force of transformation.

Our study results highlight different forms of "safe space" or Third Space experienced by students on their PhD journey. The place between dichotomies opens up space for attentiveness /mindfulness; it can be considered as a creative space. On the one hand, a Third Space can trigger a feeling of liminality that challenges people's innate social need to belong. This experience has been reported among migrant laborers (e.g., see [84]). Interestingly, however, this feeling of liminality also shows up among wealthier, transnational elites (e.g., see [85]) such as the PhD students who reported feeling "rootless" while studying abroad. On the other hand, if properly structured, such interventions can trigger an experience of being in a safe space for experimentation and transformation [25,27].

The NCCR North-South program appears to have offered students such a safe space by means of its annual summer school course, the overall program structure, its key principles of partnership, and the provision of adequate funding. In this way, students had a chance to test new modes of thinking and doing. They were able to confront learning edges and a liminal state-a "safe space" or Third Space-in which transformation could take place $[25,86]$. 
I think it's more the process to be part of this bigger project [and] to meet people to exchange, [and] to see the difficulties. I remember that it was very difficult, and there was a lot of constraints and a lot of discussions and it was not easy. And it takes a lot of time to start, to advance, to really understand the inside of the research. (Colombian woman)

Overall, the summer school course provided program participants with a "transformational space" or "learning space", in which people from diverse backgrounds could come together, discuss, listen to each other, learn together, and find compromises. Beginner students were inspired by more advanced scholars, were introduced to new fields, and had the chance to share dreams and expand their role. Acting as coaches, lecturers helped students overcome apparent dilemmas and states of frustration. Interviewees experienced this as empowering and enriching-especially because it fostered competences for interacting despite differences, enriched perspectives, and sparked new friendships. Participants were encouraged to take risks, confront complexity, step into uncertainty, and try new things [87]. These characteristics define a transformative place where education for sustainable development is possible [88-90]. In the words of Gutiérrez [91] (p. 187), we "simply cannot rely on efficiency and market-driven models of education that are certain to bankrupt the future of our nation's youth. We need models for educational intervention that are consequential — new systems that demand radical shifts in our views of learning."

Doing their PhD in Nairobi but also linked up to a university in the North, just to be able to borrow up some insights and mix them. It's more like complementing, you know? That's when I think I have seen it happening and I think that's the way that most of the things are going to go. (Kenyan woman)

Although our data offer hints, we cannot prove whether students really experienced personal transformation. Was this safe and transformative space really sufficiently inspiring and enriching for the students? Was this the beginning of a transformation for them? These are possible questions for another study, requiring a completely different questionnaire and approach. Indeed, as Jickling [92] (p. 27) points out, "we do not create transformative moments, but can create spaces for them to arise"; this presents challenges for traditional impact monitoring. While the NCCR North-South summer schools created spaces for transformation, it is unlikely that everyone experienced the same degree of transformative learning. Additionally, the present study did not investigate whether and how alumni went on to conduct engaged and transformative science after graduation, or moved into teaching in a competence-oriented way similar to the program. Furthermore, our surveys failed to capture students who dropped out for diverse reasons-reasons that would be useful to know. The final report of the program shows a dropout rate of about 10\% [63]. Another limitation is that alumni tracking studies are always marred by difficulties such as incomplete alumni databases, uncompleted questionnaires, and survey/interview declines.

\section{Conclusions and Recommendations}

In the present article, international student mobility (ISM) provided an entry point for understanding the journey of young researchers training for integration into a life of work and, simultaneously, in our sample, to join an international community of practice dedicated to striving for greater sustainability. Against the backdrop of ISM studies, reflections on global knowledge systems, inquiries into the inequalities of tertiary education, studies on the role of science for sustainable development, and reflections on spaces for transformative learning, we examined the perceptions of PhD graduates of the 12-year NCCR North-South program and analyzed the pathways of alumni through this training setting to address current global challenges. Offering students an opportunity to conduct research for sustainable development and earn a $\mathrm{PhD}$, the program was explicitly designed to address fundamental inequalities in the science landscape. Indeed, higher education institutions, in this case universities, provide a legal and infrastructural framework for tertiary education, but unfortunately also provide a basis for unequal career trajectories that isolate countries of the global South and enable Northern (Western) universities to reinforce 
their privileged position. Furthermore, universities remain organized in disciplines that provide individual careers with clear academic identities, but constrain options for systemic perspectives urgently needed to address global challenges.

The purpose of an alumni tracer study is usually to understand how individuals have benefited (or not) from a university degree in terms of their employability. In our understanding, a tracer study can do much more. It can provide indications regarding the personal growth of students, enable insights into their understanding of the purpose of their career, and illuminate their ongoing negotiation of identity.

Two alumni tracking surveys conducted in 2012 and 2017 provided the basis for the present research, complemented by several in-depth qualitative interviews. The quantitative results indicate a high degree of mobility among students during the fieldwork phase of their research, followed by two-thirds of students settling back in their country of origin following graduation. Very few students moved from the global South to the global North. Additionally, the results from both surveys showed that $\mathrm{PhD}$ degrees provide a major career boost for graduates in the global South. Furthermore, the data showed that graduates from the global South successfully obtained leading positions irrespective of whether they submitted their PhD thesis at a Northern or Southern university. In this way, our results point to "brain circulation" rather than "brain drain".

In the qualitative results, this "circulation" was further expressed in the students' statements about the important role of friendship, new networks they forged, collaboration, and a spirit of sharing. Furthermore, they valued the exchange they experienced with scientists from different disciplines as well as non-academic stakeholders.

A key learning space experienced by students was the annual summer school with its intercultural, inter-, and transdisciplinary setting, a Third Space in which students were able to develop hybrid and relational identities in a North-South research context devoted to addressing sustainability issues. Students from diverse cultural and disciplinary backgrounds were brought together in a sharing environment—or safe space—characterized by peer learning, open learning, challenges, risks, new experiences, and a focus on interand transdisciplinary research for sustainable development. On the one hand, it enabled students to test new approaches and scientific perspectives, step out of their individual comfort zone, and experience disruptive learning. This demanded openness and trust to confront uncertainty and address epistemological and power issues inherent in efforts to address sustainability in a North-South context. On the other hand, course experiences as well as the overall NCCR North-South research program, triggered a sense of liminality and rootlessness in some students, while also providing a feeling of creative possibility and ethical purpose in research. To challenge yourself and dive into this state of liminality can typically trigger transformative learning moments where students take a chance to experience a learning edge and reconsider their mindsets, provided the space made available for this experience is shaped as a safe space. In our view, such safe spaces for transformative learning are needed to tackle today's global challenges.

But how can universities transform their structures and international relations to create more of these learning spaces and enable research and teaching on behalf of sustainable development? Putting this into practice would require many Northern (Western) universities to lay down their privileges in the fundamental manner suggested by Spivak, who writes of unlearning one's privileges [93]. Moreover, a focus on collaboration instead of competition is urgently needed, also transforming power relations. Finally, a rethinking of research settings and career pathways is needed, for example, by officially recognizing and accrediting research visits and degrees from all over the world, in order to overcome postcolonial structures in academia [94]. From the perspective of educational and research policymaking, recommendations based on our insights are the following:

Educational programs should ...

$>\quad \ldots$ provide safe and innovative learning spaces where students can reflect on their mindsets and values, confront power issues inherent to research for sustainable development, and experiment new ideas to tackle today's challenges; 
$>\quad$.. bring together students from different parts of the world and different disciplines and make them work with non-academic stakeholders (inter- and transdisciplinarity);

$>$... appropriately acknowledge exchange and capacity development programs as an integral part of PhD education and provide certificates for inter- and transdisciplinary work;

$>\quad \ldots$ provide learning opportunities for trainers to create an adequately safe and creative learning environment;

$>$... support universities in the global South and North willing to adapt their curricula, in order to provide PhD degrees that will make a difference in the local and global context;

$>\quad \ldots$ and promote and enable network building.

ISM-based research should ...

$>\quad$... conduct more systematic research on North-South and South-South movement;

$>\quad \ldots$ focus on the content and aim of programs and their impact on alumni's expected career pathways in sustainable development;

$>\quad \ldots$ and gather more alumni data including type of subjects, experience with spaces for learning, diversity of steps into the labor market (including academic careers starting with PhD programs), potential remaining links to home university, who stays abroad and who returns.

Supplementary Materials: The following are available online at https://www.mdpi.com/2071 -1050/13/4/2413/s1, Questionnaires: Supplementary A-Questionnaire Alumni Tracking 2012, Supplementary B-Questionnaire Alumni Tracking 2017.

Author Contributions: Conceptualization, L.J.T., A.B.Z., C.S., T.B., K.H. and S.T.; Methodology, L.J.T., A.B.Z., C.S. and S.T.; Validation, L.J.T., A.B.Z., C.S. and S.T.; Formal analysis, L.J.T. and C.S.; Investigation, L.J.T. and C.S.; Data curation, L.J.T. and C.S.; Writing-Original draft preparation, L.J.T. and A.B.Z.; Writing-Review and editing, L.J.T., A.B.Z., C.S., T.B., K.H. and S.T.; Visualization, L.J.T. and C.S.; Supervision, A.B.Z., T.B. and S.T.; Project administration, L.J.T. and C.S.; Funding acquisition, T.B. All authors have read and agreed to the published version of the manuscript.

Funding: This research received no external funding.

Institutional Review Board Statement: Not applicable.

Informed Consent Statement: Informed consent was obtained from all subjects involved in the study.

Data Availability Statement: The data presented in this study are available on request from the corresponding author. The data are not publicly available due to confidentiality agreements with the interviewees.

Acknowledgments: We would like to thank all participants in the survey, particularly, our interviewees for generously giving their time and insights. Many thanks also go to Anu Lannen for his constructive and insightful editing of the manuscript, and to the three anonymous reviewers, whose comments helped to sharpen our argument and considerably improve the paper.

Conflicts of Interest: The authors declare no conflict of interest.

\section{References}

1. Trechsel, L.J.; Zimmermann, A.B.; Graf, D.; Herweg, K.; Lundsgaard-Hansen, L.; Rufer, L.; Tribelhorn, T.; Wastl-Walter, D. Mainstreaming Education for Sustainable Development at a Swiss University: Navigating the Traps of Institutionalization. High. Educ. Policy 2018, 31, 471-490. [CrossRef]

2. Findlay, A.M.; King, R.; Smith, F.M.; Geddes, A.; Skeldon, R. World class? An investigation of globalisation, difference and international student mobility. Trans. Inst. Br. Geogr. 2012, 37, 118-131. [CrossRef]

3. Waters, J.L. Education unbound? Enlivening debates with a mobilities perspective on learning. Prog. Hum. Geogr. 2016, 41, 279-298. [CrossRef]

4. Baláž, V.; Williams, A.M.; Chrančoková, M. Connectivity as the facilitator of intra-European student migration. Popul. Space Place 2017, 24, e2101. [CrossRef] 
5. King, R.; Raghuram, P. International Student Migration: Mapping the Field and New Research Agendas. Popul. Space Place 2013, 19, 127-137. [CrossRef]

6. UNESCO. UNESCO Science Report: Towards 2030; United Nations Educational, Scientific and Cultural Organization (UNESCO): Paris, France, 2015.

7. Grimshaw, T.; Sears, C. Where am I from? Where do I belong?' The negotiation and maintenance of identity by international school students. J. Res. Int. Educ. 2008, 7, 259-278. [CrossRef]

8. Phelps, J.M. International Doctoral Students' Navigations of Identity and Belonging in a Globalizing University. Int. J. Dr. Stud. 2016, 11, 001-014. [CrossRef]

9. Rizvi, F. International Students and Doctoral Studies in Transnational Spaces. In The Routledge Doctoral Supervisor's Companion. Supporting Effective Research in Education and the Social Sciences; Walker, M., Thomson, P., Eds.; Routledge: New York, NY, USA, 2010; Volume 1, pp. 158-170.

10. Campbell, A.C.; Kelly-Weber, E.; Lavallee, C. University teaching and citizenship education as sustainable development in Ghana and Nigeria: Insight from international scholarship program alumni. High. Educ. 2021, 81, 129-144. [CrossRef]

11. Martel, M. Leveraging Higher Education to Promote Social Justice: Evidence from the IFP Alumni Tracking Study; Institute of International Education: New York, NY, USA, 2019.

12. Martel, M.; Bhandari, R. Social Justice and Sustainable Change: The Impacts of Higher Education. Ford Foundation International Fellowships Program Alumni Tracking Study; Institute of International Education: New York, NY, USA, 2016.

13. Campbell, A.C.; Baxter, A.R. Exploring the attributes and practices of alumni associations that advance social change. Int. J. Educ. Dev. 2019, 66, 164-172. [CrossRef]

14. Messerli, P.; Kim, E.M.; Lutz, W.; Moatti, J.-P.; Richardson, K.; Saidam, M.; Smith, D.; Eloundou-Enyegue, P.; Foli, E.; Glassman, A.; et al. Expansion of sustainability science needed for the SDGs. Nat. Sustain. 2019, 2, 892-894. [CrossRef]

15. Schneider, F.; Kläy, A.; Zimmermann, A.B.; Buser, T.; Ingalls, M.; Messerli, P. How can science support the 2030 Agenda for Sustainable Development? Four tasks to tackle the normative dimension of sustainability. Sustain. Sci. 2019, 14, 1593-1604. [CrossRef]

16. United Nations. The Future Is Now-Science for Achieving Sustainable Development (Global Sustainable Development Report 2019); United Nations-Department of Economic and Social Affairs: New York, NY, USA, 2019.

17. Sterling, S. Assuming the Future: Repurposing Education in a Volatile Age. In Post-Sustainability and Environmental Education; Jickling, B., Sterling, S., Eds.; Palgrave Macmillan: Cham, Switzerland, 2017; pp. 31-45.

18. Leicht, A.; Heiss, J.; Byun, W.J. Issues and trends in Education for Sustainable Development; United Nations Educational, Scientific and Cultural Organization: Paris, France, 2018.

19. Barth, M.; Lang, D.J.; Michelsen, G. Transdisciplinary learning to foster sustainable development: Institutionalizing co-engaged South-North collaboration. GAIA-Ecol. Perspect. Sci. Soc. 2019, 28, 382-385. [CrossRef]

20. Villeneuve, D.; Durán-Rodas, D.; Ferri, A.; Kuttler, T.; Magelund, J.; Mögele, M.; Nitschke, L.; Servou, E.; Silva, C. What is Inter-disciplinarity in Practice? Critical Reflections on Doing Mobility Research in an Intended Interdisciplinary Doctoral Research Group. Sustainability 2020, 12, 197. [CrossRef]

21. Wiek, A.; Withycombe, L.; Redman, C.L. Key competencies in sustainability: A reference framework for academic program development. Sustain. Sci. 2011, 6, 203-218. [CrossRef]

22. Barth, M. Implementing Sustainability in Higher Education: Learning in an Age of Transformation; Routledge: Abingdon, UK, 2015.

23. Herweg, K.; Zimmermann, A.B.; Lundsgaard-Hansen, L.; Tribelhorn, T.; Hammer, T.; Tanner, R.P.; Trechsel, L.J.; Bieri, S.; Kläy, A. Integrating Sustainable Development into Higher Education-Guidelines with In-depth Modules for the University of Bern; Foundations; University of Bern, Vice-Rectorate Quality, Vice-Rectorate Teaching, Centre for Development and Environment (CDE), Educational Development Unit (ZUW), and Bern Open Publishing (BOP): Bern, Switzerland, 2017. [CrossRef]

24. Kläy, A.; Zimmermann, A.B.; Schneider, F. Rethinking science for sustainable development: Reflexive interaction for a par-adigm transformation. Futures 2015, 65, 72-85. [CrossRef]

25. Förster, R.; Zimmermann, A.B.; Mader, C. Transformative teaching in Higher Education for Sustainable Development: Facing the challenges. GAIA-Ecol. Perspect. Sci. Soc. 2019, 28, 324-326. [CrossRef]

26. Thieme, S.; Fry, P. Transdisziplinarität erleben-Prinzipien für die universitäre Lehre. In Prinzipien, Strukturen und Praktiken geographischer Hochschullehre; Wintzer, J., Mosing, I., Hof, A., Eds.; UTB: Stuttgart, Germany, Forthcoming.

27. Tillmanns, T. Learning sustainability as an effect of disruption. Environ. Educ. Res. 2019, 26, 14-26. [CrossRef]

28. Sallah, M. Generating disruptive pedagogy in informal spaces: Learning with both the head and the heart. Vzgoja Izobr. 2020, $51,16$.

29. Kläy, A.; Schneider, F. Zwischen Wettbewerbsfähigkeit und nachhaltiger Entwicklung: Forschungsförderung braucht Politikkohärenz. GAIA-Ecol. Perspect. Sci. Soc. 2015, 24, 224-227. [CrossRef]

30. Baumann, C.; Dietze, A.; Maruschke, M. Managing Processes of Globalization: A Spotlight on the University as a Key Institution in the 21th Century. Comparativ. Z. Glob. Vgl. Ges. 2017, 27, 168-202.

31. Kölbel, A.; Thieme, S.; Pfaff-Czarnecka, J. Universities as Transformative Social Spaces: Mobilities and Mobilisations from South Asian Perspectives; Oxford University Press: Oxford, UK, 2021; Forthcoming/print March 2021.

32. Lindberg, E.; Chakrabarti, P.; Thieme, S. Brain Drain or Brain Circulation? Career Paths of International Students: Swiss Scholarships for International Students at ETH Zurich and the University of Zurich; ETH Global, ETHZ and UZH: Zurich, Switzerland, 2014. 
33. Riaño, Y.; Lombard, A.; Piguet, E. The Global Race for Talent in Switzerland. How to Explain Migration Policy Liberalisation to Allow International Students Staying after Graduation? Working Paper \#14; NCCR on the Move: Neuchâtel, Switzerland, 2017; pp. 1-20.

34. NCCR North-South. Partnerships in Research for Sustainable Development. Research Highlights and Their Implications for Policy and Practice; Centre for Development and Environment (CDE) and National Centre of Competence (NCCR) North-South: Bern, Switzerland, 2013.

35. UNESCO. UNESCO Online Databank. Available online: http:/ / data.uis.unesco.org/Index.aspx?queryid=172 (accessed on 27 February 2020).

36. Madge, C.; Raghuram, P.; Noxolo, P. Engaged pedagogy and responsibility: A postcolonial analysis of international students. Geoforum 2009, 40, 34-45. [CrossRef]

37. Kölbel, A. Imaginative geographies of international student mobility. Soc. Cult. Geogr. 2020, 21, 86-104. [CrossRef]

38. Hannerz, U. Cultures, People, Places; Routledge: London, UK, 1996.

39. Baas, M. Students of migration: Indian overseas students and the question of permanent residency. People Place 2006, 14, 9-24.

40. Tilly, C.; Brown, C.H. On Uprooting, Kinship, and Auspices of Migration. Int. J. Comp. Sociol. 1967, 8, 139-164. [CrossRef]

41. Boyd, M. Familial and Personal Networks in International Migration: Recent Development and New Agendas. Int. Migr. Rev. 1989, 23, 638-670. [CrossRef]

42. Portes, A.; Sensenbrenner, J. Embeddedness and Immigration: Notes on the Social Determinants of Economic Action. Am. J. Sociol. 1993, 98, 1320-1349. [CrossRef]

43. Thieme, S. Social Networks and Migration. Far West Nepalese Labour Migrants in Delhi; LIT: Münster, Germany, 2006; Volume 7, p. 243.

44. United Nations. Transforming our World: The 2030 Agenda for Sustainable Development. A/RES/70/1; United Nations: New York, NY, USA, 2015.

45. Alff, H.; Berny, A. Tracing Connection: Explorations of Spaces and Places. In Tracing Connection: Explorations of Spaces and Places in Asian Contexts; Alff, H., Berny, A., Eds.; Wissenschaftlicher Verlag: Berlin, Germany, 2014; pp. 7-20.

46. Beech, J.; Larsen, M.A. Replacing Old Spatial Empires of the Mind. Eur. Educ. 2014, 46, 75-94. [CrossRef]

47. Lange, E.A. Transforming Transformative Education Through Ontologies of Relationality. J. Transform. Educ. 2018, 16, 280-301. [CrossRef]

48. Cresswell, T. Mobilities I: Catching up. Prog. Hum. Geogr. 2010, 35, 550-558. [CrossRef]

49. Sheller, M.; Urry, J. The New Mobilities Paradigm. Environ. Plan. A Econ. Space 2006, 38, 207-226. [CrossRef]

50. Massey, D. Power geometry and a progressive sense of place. In Mapping the Futures. Local Cultures, Global Change; Bird, J., Curtis, B., Putnam, T., Robertson, G., Tickner, L., Eds.; Routledge: London, UK; New York, NY, USA, 1993.

51. Lange, E.A. Transformative learning and concepts of the self: Insights from immigrant and intercultural journeys. Int. J. Lifelong Educ. 2015, 34, 623-642. [CrossRef]

52. Bhabha, H.K. In the cave of making. Thoughts on third space. In Communicating in the Third Space; Ikas, K., Wagner, G., Eds.; Routledge: New York, NY, USA, 2009; pp. 9-14.

53. Jöns, H. Brain circulation and transnational knowledge networks: Studying long-term effects of academic mobility to Germany, 1954-2000. Glob. Netw. 2009, 9, 315-338. [CrossRef]

54. Lowell, B.L.; Findlay, A.M.; Steward, E. Brain Strain: Optimising Highly Skilled Migration from Developing Countries; Migration Working Paper 3; Institute for Public Policy Research: London, UK, 2004; pp. 1-41.

55. Thieme, S. An international degree, social ties and return: When international graduates make a career back home in Kyr-gyzstan. Int. Asienforum 2014, 45, 113-128.

56. Thieme, S. Coming Home? Patterns and Characteristics of Return Migration in Kyrgyzstan. Int. Migr. 2012, 52, 127-143. [CrossRef]

57. Wolfeil, N. Auswirkungen des Auslandstudiums auf spätere Mobilitäts- und Karrieremuster. Das Beispiel der Polnischen Studierenden an Deutschen Hochschulen; Vienna University Press: Göttingen, Germany, 2012.

58. Heim, E.M.; Engelage, S.; Zimmermann, A.B.; Herweg, K.; Michel, C.; Breu, T. Tracking Alumni Career Paths: Third NCCR North-South Report on Effectiveness; NCCR North-South Dialogue, Management Centre, Centre for Development and Environment (CDE), University of Bern: Bern, Switzerland, 2012.

59. Bahna, M. Study choices and returns of international students: On the role of cultural and economic capital of the family. Popul. Space Place 2017, 24, e2082. [CrossRef]

60. Bjørsted, A. Denmark: Danish Degree students abroad: What can register data tell us? In Nordic Students Abroad. Student Mobility Patterns, Student Support Systems and Labour Market Outcomes; Saarikallio-Torp, M., Wiers-Jenssen, J., Eds.; Kela Research Department: Helsinki, Finland, 2010; pp. 119-128.

61. Wiers-Jenssen, J. Degree Mobility from the Nordic Countries. J. Stud. Int. Educ. 2013, 17, 471-491. [CrossRef]

62. Zingerli, C. A Sociology of International Research Partnerships for Sustainable Development. Eur. J. Dev. Res. 2010, 22, 217-233. [CrossRef]

63. Hurni, H.; Breu, T.; Wiesmann, U. NCCR North-South Final Report, 1.7.2001-30.6.2013. [Internal Report]; NCCR North-South: Bern, Switzerland, 2013; pp. 1-82. 
64. Stöckli, B.; Wiesmann, U.; Lys, J.-A. A Guide for Transboundary Research Partnerships: 11 Principles, 3rd ed.; Swiss Commission for Research Partnerships with Developing Countries (KFPE), Ed.; KFPE, Swiss Academy of Sciences, and Swiss National Science Foundation: Bern, Switzerland, 2018.

65. Upreti, B.R.; Zimmermann, A.B.; Debele, B.; Cissé, G. Partnerships in Development-oriented Research. Lessons Learnt and Challenges Ahead; NCCR North-South, South Asia Coordination Office: Kathmandu, Nepal, 2012.

66. Herweg, K.; Schäfer, N.; Zimmermann, A. Guidelines for Integrative Training in Inter- and Transdisciplinary Research Settings: Hints and Tools for Trainers of Trainers; NCCR North-South and Centre for Development and Environment (CDE): Bern, Switzerland, 2012; p. 64. [CrossRef]

67. Madge, C.; Raghuram, P.; Noxolo, P. Conceptualizing international education. Prog. Hum. Geogr. 2014, 39, 681-701. [CrossRef]

68. Johnson, R.B.; Onwuegbuzie, A.J.; Turner, L.A. Toward a Definition of Mixed Methods Research. J. Mix. Methods Res. 2007, 1, 112-133. [CrossRef]

69. Baruch, Y. Response Rate in Academic Studies-A comparative Analysis. Hum. Relat. 1999, 52, 421-438. [CrossRef]

70. Baruch, Y.; Holtom, B.C. Survey response rate levels and trends in organizational research. Hum. Relat. 2008, 61, 1139-1160. [CrossRef]

71. Morton, S.M.; Bandara, D.K.; Robinson, E.M.; Carr, P.E. In the 21st Century, what is an acceptable response rate? Aust. N. Z. J. Public Health 2012, 36, 106-108. [CrossRef]

72. United Nations. United Nations Development Programme Human Development Reports. Available online: http:/ hdr.undp. org/en/composite/HDI (accessed on 27 September 2020).

73. Beaudry, C.; Mouton, J.; Prozesky, H.E. The Next Generation of Scientists in Africa; African Minds: Cape Town, South Africa, 2018.

74. Flick, U. Designing Qualitative Research; SAGE Publications Pvt Ltd.: London, UK, 2007.

75. Döring, N.; Bortz, J. Forschungsmethoden und Evaluation in den Sozial- und Humanwissenschaften; Springer-Lehrbuch; 5. Vollständig überarbeitete Ausgabe; Springer: Berlin/Heidelberg, Germany, 2016; ISBN 978-3-642-41089-5.

76. Hayward, F.M.; Ncayiyana, D.J. Confronting the Challenges of Graduate Education in Sub-Saharan Africa and Prospects for the Future. Int. J. Afr. High. Educ. 2014, 1, 43. [CrossRef]

77. Fokou, G.; Liechti, K.; Abdiev, A.; Kozhomurato, J. North-South Exchange-Research in JACS ALPS. In Report of the Study on Institutions and Mechanisms Regulating Swiss Alpine Pasture Use and the Marketing of Pastoral Products [Internal Report]; National Centre of Competence in Research (NCCR) North-South: Bern, Switzerland, 2008.

78. Liechti, K. Forschungspartnerschaften und Weidenutzungsfragen. GeoAgenda 2008, 4-5, 4-5.

79. Kahn, M.; Gamedze, T.; Oghenetega, J. Mobility of sub-Saharan Africa doctoral graduates from South African universities-A tracer study. Int. J. Educ. Dev. 2019, 68, 9-14. [CrossRef]

80. Pohl, C.; Rist, S.; Zimmermann, A.; Fry, P.; Gurung, G.S.; Schneider, F.; Speranza, C.I.; Kiteme, B.; Boillat, S.; Serrano, E.; et al. Researchers' roles in knowledge co-production: Experience from sustainability research in Kenya, Switzerland, Bolivia and Nepal. Sci. Public Policy 2010, 37, 267-281. [CrossRef]

81. NCCR North-South. Publication Strategy for the NCCR North-South, Phase 3 (Revised Version of Phase 2 Document). First Version: 2006 [Internal Report]; Management Centre of the NCCR North-South: Bern, Switzerland, 2010.

82. State Secretariat for Education, Research and Innovation (SERI). University Rankings Results. Available online: https://www. universityrankings.ch/ (accessed on 28 April 2020).

83. Hurni, H.; Wiesmann, U. Transdisciplinarity in Practice. Experience from a Concept-based Research Programme Addressing Global Change and Sustainable Development. GAIA-Ecol. Perspect. Sci. Soc. 2014, 23, 275-277. [CrossRef]

84. Killias, O. Intimate encounters: The ambiguities of belonging in the transnational migration of Indonesian domestic workers to Malaysia. Citizsh. Stud. 2014, 18, 885-899. [CrossRef]

85. Colic-Peisker, V. Free floating in the cosmopolis? Exploring the identity-belonging of transnational knowledge workers. Glob. Netw. 2010, 10, 467-488. [CrossRef]

86. Sterling, S. Transformative Learning and Sustainability: Sketching the conceptual ground. Learn. Teach. High. Educ. 2011, 5, 17-33.

87. Lange, E.A. Transformative and Restorative Learning: A Vital Dialectic for Sustainable Societies. Adult Educ. Q. 2004, 54, 121-139. [CrossRef]

88. Lotz-Sisitka, H.; Wals, A.E.J.; Kronlid, D.; McGarry, D. Transformative, transgressive social learning: Rethinking higher education pedagogy in times of systemic global dysfunction. Curr. Opin. Environ. Sustain. 2015, 16, 73-80. [CrossRef]

89. Wals, A.E.J. Social Learning towards a Sustainable World: Principles, Perspectives, and Praxis; Wageningen Academic Publishers: Wageningen, The Netherlands, 2007.

90. Wals, A.E. Sustainability in higher education in the context of the UN DESD: A review of learning and institutionalization processes. J. Clean. Prod. 2014, 62, 8-15. [CrossRef]

91. Gutiérrez, K.D. Designing Resilient Ecologies: Social Design Experiments and a New Social Imagination. Educ. Res. 2016, 45, 187-196. [CrossRef]

92. Jickling, B. Education revisited: Creating educational experiences that are held, felt, and disruptive. In Post-Sustainability and Environmental Education, 1st ed.; Jickling, B., Sterling, S., Eds.; Palgrave Macmillan: Cham, Switzerland, 2017; pp. 15-30. [CrossRef] 
93. Spivak, G.C. Can the Subaltern Speak? In Marxism and the Interpretation of Culture; Nelson, C., Grossberg, L., Eds.; University of Illinois Press: Urbana, IL, USA; Chicago, IL, USA, 1988; pp. 271-313.

94. Trechsel, L.J.; Steinböck, C.; Ayeri Ogalleh, S.; Zimmermann, A.B.; Herweg, K.; Breu, T.; Lannen, A. Unlocking Knowledge for Sustainability: Partnership-Based Research and Education; CDE Policy Brief, No. 17; Centre for Development and Environment (CDE): Bern, Switzerland, 2020. 